\title{
Policy Evaluation National-Standard School Exams in Bondowoso Regional Education Branch
}

\author{
Mahrus Syamsul \\ Student of Doctor Study Program of Administration Sciences - FISIP, Universitas 17 Agustus 1945 Surabaya, \\ Jl. Semolowaru No. 45 Surabaya, Jawa Timur, Indonesia
}

Arif Darmawan

Joko Widodo

\begin{abstract}
The purpose of this study is to describe the level of effectiveness, identify and describe inhibiting factors, describe the impact, determine the policy recommendations for the implementation of NSSE. The objects of research are Ibrahimy Vocational High School. Data collection methods use observation, interviews, documentation, triangulation. The research instruments, interview guidelines, and recording equipment. That the effectiveness of smartphone-based NSSE includes: (1) As many as 100\% of participants like school exams to use smartphones. (2) Smartphone-based exams are far more effective than computer exams. Inhibiting factors include: There is no emphasis from the Head of the East Java Provincial Education Office. Impact: Teachers no longer bother to correct and do not need to process grades. The integrity of participants in carrying out school exams reaches $100 \%$. Policy recommendations: Recommending the Head of the Education Office does not recommend, but emphasizes.
\end{abstract}

Keywords: Policy evaluation, National Standard School Exams

DOI: $10.7176 / \mathrm{PPAR} / 10-6-05$

Publication date:June 30th 2020

\section{Preliminary}

At the national level, NSST is implemented in two modes. First, the Paper and Pencil Based National Standard School Examination (PP-BNSSE). Second, the National Standard School Examination based on Computers and Smartphones (NSSE-CS). In East Java, NSST is implemented based on Computers and Smartphones only. That means in East Java there is no pencil paper based school exam.

The total population of Indonesia in 2019 will reach 267 million. This data was provided by Bapenas in 2019. While the number of mobile phone users in Indonesia reached $142 \%$. This data is sourced from We Are Social in January 2017. That number exceeds $100 \%$, meaning that the number of mobile phones owned by Indonesian residents is greater than the number of Indonesian residents themselves. Because of that we understand that one person has one cellphone or even one person might have two cellphones.

The average prediction of students in East Java already has a cellphone. Then the question arises. How is the implementation of the National Standard School Examination in East Java.Especially how the implementation of smartphone-based National Standard School Exams.How about a pencil-based USBN in the Bondowoso District Education Office Branch.

\section{Library Review}

There are some previous studies that have been done by several researchers.

National Standard School Exams (NSSE) Held For 11 Days, By: Matholi'ul Huda, 2019. It turns out that research compiled by Matholi'ul Huda revealed about the implementation of the National Standard School Examination which no longer uses paper and pencil, but has used computer. Usually School Exams are conducted with paper and pencil, but this year School Examination activities have been carried out using computer equipment.

Because the National Standard School Exams this year are computer-based, for one day the implementation is only testing one subject. That is because there are still limited computer infrastructure, even in other madrasa there are those who carry out up to 3 exam sessions in one day. For this reason, NSSE is scheduled to be very long this year, which is held for 11 days. Namely the first week of March 2019 from the 1st to the 9th of March 2019 and the dikebud in the last week of March 2019 from March 23-27 2019.

Even though NSSE has been computer-based this time, it still seems that the preparation of the ministry of religion is not yet mature in its implementation. Unlike the Computer Based National Standard Madrasah Final Examination(CBNSMFE) and Computer-Based National Exams(CBNE) madrasah servers only synchronize automatically from all questions, minutes, results reports and others. neatly uploaded. In contrast to USBN this time it still uses a manual method to upload the questions and sort out which ones are worth testing. Hopefully in the future be prepared again so that everything works better and more effectively.

Performance Evaluation on DKI Jakarta Provincial Government Policy.By Abdul Razak (2002). Abdul Razak 
conducted a study on Performance Evaluation on DKI Jakarta Provincial Government Policy relating to the implementation of the Clean Kali program through system dynamics modeling, finding that the performance of the Clean Kali program implementation would achieve the target if the implementers were committed to the rules of predetermined performance standards,

The higher the commitment of implementation, the performance of the executor in administration will increase for that required administrative control continuously and continuously. Through the use of dynamic system analysis, the Clean Kali program policy as a system in which all variable elements interact with one another in a domain. The findings of this study are interactions between elements of Public Administration, elements of Bureaucratic Performance and elements of good governance.

\section{Research methods}

This research is about evaluating public policy, so this research uses descriptive qualitative method. Then the evluation system model that will be used is the model made by Stufflebeam namely the CIPP (Contect, Input, Process, Product) model. Research approach used in this research is qualitative research. As the main object in this study is the agency implementing the smartphone-based school exams, namely private vocational IbrohimySitubondo. In addition, institutions that carry out School Exams that are not based on smartphones are also the object of this study, namely SMA Negeri 1 PrajekanBondowoso. Data collection conducted in this study uses the following: Observation, Interview, Documentation, Triangu-lation. Research instruments include: The Researcher Himself, Interview Guidelines, Recording Tools. Data Analysis Techniques with Data Reduction, Data Presentation, Drawing Conclusions.

\section{Discussion}

Through CIPP, researchers do not only conduct evaluations at the beginning and end. The researcher will evaluate the inputs and processes as well.

\section{Context Evaluation}

That the National Standard School Examination is an activity to measure the achievement of student competencies carried out by the school by adhering to Graduates Competency Standards. Nationally, that the National Standard School Exams are carried out in two categories. The first category is the National Paper School Based Pencil Exam and the Computer and Smartphone Based National Standard School Exam. Legal Basis for implementing High school national standard school examinations include; 1) Law of the Republic of Indonesia Number 20 Year 2003 , 2) Government Regulation Number 19 of 2005, 3) Government Regulation Number 55 of 2007, 4) Government Regulation Number 17 of 2010, 5) Regulation of the Minister of Religion of the Republic of Indonesia Number 7 of 2012 , 6) Regulation of the Minister of Religion of the Republic of Indonesia Number 13 of 2014, 7) Regulation of the Minister of Religion of the Republic of Indonesia Number 54 of 2014, 8) Regulation of the Minister of National Education Number 23 of 2006. The legal basis for implementing the National Vocational School-based school exams includes; 1) Act Number 20 of 2003, 2) Government Regulation Number 19 of 2005, 3) Government Regulation Number 55 of 2007, 4) Government Regulation Number 17 of 2010, 5) Regulation of the Minister of Religion of the Republic of Indonesia Number 7 of 2012, 6 ) Regulation of the Minister of Religion of the Republic of Indonesia Number 13 of 2014, 7) Regulation of the Minister of Education and Culture Number 20 of 2016, 8) Regulation of the Minister of Education and Culture Number 21 of 2016.

\section{Input Evaluation}

After conducting in-depth interviews with the head of SMK IbrahimySitubondo, the researchers obtained data. The data include the budget. The National Standardized School Examination, Expertise Competency Test, National Examination, and School Examination, have been clearly budgeted by the institution.

Personnel involved in Smartphone-Based National Standard School Exams come from Educators and Education Personnel. There are currently 30 educators, while there are 6 teaching staff. Of these, they will be involved in supervisors, technicians, and actor staff. The number of supervisors required in the implementation of Smartphone-Based National Stan-dard School Exams is in accordance with the number of exam rooms. One exam room is needed by one exam supervisor.

According to the Principal at Ibrahimy Private Vocational School the important facilities needed to carry out the exam only prepare the network infrastructure in accordance with the existing topology in the form of computer servers, access points and network cables that are used as a link between network devices. Infrastructure that is important in the implementation of the National Standard School Examination with Smartphone Based is a signal. Which is a very important tool in the implementation of smartphone-based school exams is a mobile device or smartphone.

Organizations involved in implementing the National Standard School Exams with a Smartphone Based are the Head of the Education Office Branch, the Head of the High School / PKLK and the Head of the Vocational 
School and several Principals.

\section{Process Evaluation}

During the process, evidence was found that none of the students missed the questions. They all answered the questions provided. This means that the blank answers by students are absent. Besides that it turned out that all students started working on the questions at the same time. They start right at 07.00. And it turns out all students end working on the same time also at 09.00 . The value of each student participating in the school exam can be known when students log out. Seconds can also be known the value of each student. Researchers also found evidence that in the implementation of school examinations in the 2018/2019 school year, none of the institutes conducted pencil-based school examinations. And institutions that carry out smartphone-based school exams in Bondowoso district, Situbondo district are only 5 institutions. Whereas the total number of institutions is 136 . Thus, the institutions that carry out school exams with smartphones are only $3.67 \%$.

It turned out that all (100\%) smartphone-based school exam participants were happy to use a smartphone. feel relaxed in working on school exam questions, not tense when working on questions by using a Cellphone. They do not like to take the exam using the computer, do not enjoy if the exam using the computer feel tense taking the school exam using a computer plane. At the time of the exam it turned out that no one asked each other questions or answers each other, not even visible between students working together. The integrity of participants in carrying out school exams reaches $100 \%$.

The application used in the exam is the Exambro application. During activating the Ex-ambro Application, all applications will automatically become inactive.

\section{Product Evaluation}

Researchers found evidence of teacher responses to the Smartphone-Based School Exams. That the number of subject teachers tested in USBN is 24 people. Of this number there are 24 people who like the policy of Smartphone-Based School Exams. So as much as $100 \%$ like, and $0 \%$ dislike. It turns out that the school exam using a smartphone is more efficient than using a computer.

The responses of various elements to the implementation of the Smartphone-Based National Standard School Exams: 1) The school committee representing all student parents stated that it strongly supports the implementation of smartphone-based school exams. 2) Students who take smartphone-based examinations state that smartphones are not only used for playing games but can be used for examinations. 3) Students who take the exam use a computer, stating that there are 7 out of 10 people who say they enjoy using a computer. 4) Teachers at the smartphone-based Executing Agency say that, greatly reducing the teacher's work in correcting. 5) The teachers like and agree with the implementation of school exams using smartphones. And it turns out that all school residents agree with the smartphone-based school exam Except for Administrative staff and employees. There are 1 in 7 administrative staff who disagree with the smartphone-based school exam. 6) Parents of Students Who Take the Smartphone Using Exam, welcome the smartphone-based test. 7) Chairperson of PGRI Bondowoso stated that there were no negative reports on the implementation of school examinations using smartphones. That means the test with a smartphone runs smoothly, orderly and successfully. 8) School Principals in Institutions that do not carry out Smartphone-Based Exams, stated determined to use the Smartphone in the implementation of the semester re-examination and the repeat test in the next semester.

\section{Conclusion}

As many as $100 \%$ of smartphone-based exam participants feel happy about school exams using their own cellphones. Students feel enjoy during the exam using a cellphone. They feel relaxed in working on school exam questions. In addition, the researchers also found evidence that the examinees did not feel tense when working on questions using a cellphone. They did not like taking the school exam using the computer. Examination using a smartphone will be far more effective than a test using pencil paper. Even more effective than a test using a computer. From a financial perspective, it turns out that the implementation of school exams using a smartphone is more efficient than using a computer.

The main factor that greatly influenced the implementation of the policy was that there was no emphasis from the Head of the East Java Provincial Education Office so that institutions in East Java use smartphones in the implementation of School Exams in each institution. Another limiting factor is the false presumption of teachers in institutions that have not used smartphones.

Impact of this policy Teachers no longer bothered to correct after the test. Even the teachers are no longer busy to determine score, and even no longer takes time to determine grades.

None of the teachers at IbrahimySitubondo Private Vocational School disagreed with the implementation of school exams using smart-phones. All school residents agree with the smartphone-based school exam. Except for Administrative staff and employees. There are 1 in 7 administrative staff who disagree with the smartphone-based school exam. 
The researcher recom-mends that the Head of Service not only limited to conveying about the implementation of smartphone-based school exams. However, the Head of Service emphasized and even required that institutions carry out smartpohone-based school exami-nations.

Because smartphone-based NSSE has a good level of effectiveness. Good effect. High integrity value. The researchers' recommendation is a smartphone-based NSSE policy to be followed by several notes. His notes are the head of the Education Office giving emphasis.

\section{Bibliography}

Abdul, Wahab.,danSolichin. (2004). Analisis Kebijakandari Formasike Implementasi .Kebijaksanaan Negera. EdisiKedua. Jakarta :BumiAksara.

Abu-Duhou, I. (2003). School-Based Management.Jakarta : Logos WacanaIlmu.

AgusSalim. (2006). Teoridan Paradigma Penelitian Sosial ;Buku Sumber Untuk Penelitian Kualitatif , Edisi 1.Yogyakarta : Tiara Wacana.

Ahmadi, A. dan N. Uhbiyati. 2017. IlmuPendidikan. Jakarta: PT RinekaCipta.

Alawiyah.F. (2012). "KebijakandanPengembangan Pembangunan Karakter Melalui Pendidikan di Indonesia”.Aspirasi. 3 (1): 87-101.

Arikunto, S. (2018). Dasar-dasar Evaluasi Pendidikan.Edisi 3. Jakarta: Bumi Aksara.

Bambang.(2014). Sutradara Pendidikan.Jakarta : PT Alex Media Komputindo.

Birland, AT.(2001). Policy Process, Theories, Concept and Models of Public Policy Making. New York, USA: M.E Sharpe

Bungin, B. (2008). Penelitian Kualitatif. Jakarta :Persada Media group.

Bungin, B. Sukristyanto, A. Rudy, V. (2016).Buku Pedoman Penulisan MKPD, Proposal, dan Disertasi Program Studi Doktor Ilmu Administrasi. Surabaya :Prenadamedia Group.

BurhanBungin.(2012). Penelitian Kualitatif; Komunikasi, Ekonomi, Kebijakan Publikdan Ilmu Sosiallainnya, Edisi Kedua. Jakarta :KencanaPrenada Media Group.

Widodo, J. (2003). Akuntabilitas Birokrasi Publik, Studi Evaluasi Pelaksanaan Kebijakan Akuntabilitas KinerjaInstansi Pemerintah di Kabupaten Sidoarjo. UntagSurabaya :DisertasiTidakDiterbitkan.

Widodo, J. (2018). “Analisis Kebijakan Publik”. Malang: Media Nusa Creative

Winarno.(2012). KiatSukses Menjadi Penulis, Menjadi Profesional Berdaya Saing Tinggi. Jakarta : Platinum.

Zaidan, N . (2013). Managemen Pemerintahan, Cetakan Pertama. Jakarta : Raja Grafindo Perkasa. 